\title{
Immune responses to Helicobacter pylori in children with recurrent abdominal pain
}

\author{
J E Crabtree, M J Mahony, J D Taylor, R V Heatley, J M Littlewood, D S Tompkins
}

\begin{abstract}
The systemic immune response to Helicobacter pylori was examined in 69 children with recurrent abdominal pain and upper gastrointestinal symptoms. Twenty one (30\%) children were histologically positive for $H$ pylori. Eighteen of the 21 positive subjects and two $H$ pylori negative subjects (one with normal mucosa, one with lymphocytic gastritis) were positive for $H$ pylori IgG antibodies by enzyme linked immunosorbent assay (ELISA) ( $86 \%$ sensitivity, $\mathbf{9 8} \%$ specificity). In children with $H$ pylori associated gastritis, there was a significant positive correlation $(p<0.05)$ between IgG antibody titres and patient age. Intra-assay comparison of sera from histologically negative adults with those of histologically negative children showed that the cut off for positivity in the ELISA for adults was greater than that for children. Immunoblotting showed IgG positivity in 20 of the 21 patients with $H$ pylori infection $(95 \%$ sensitivity). Both ELISA and immunoblotting for IgA and IgM $H$ pylori antibodies had poor discriminatory value for determining infection.

Serological detection of $\boldsymbol{H}$ pylori IgG antibodies seems to be valuable in the assessment of children presenting with recurrent abdominal pain and other gastrointestinal symptoms, but assays must first be validated in paediatric populations.
\end{abstract}

The strong association between gastric Helicobacter pylori colonisation, gastritis, and peptic ulcer disease in adults is now firmly established. ${ }^{12} H$ pylori colonisation results in a systemic IgG response, ${ }^{3-8}$ and serology has been strongly advocated as a suitable means of screening adult dyspeptic patients. ${ }^{910}$ Epidemiological studies have shown that childhood infection with $H$ pylori in the West is generally low (less than $5 \%$ ). ${ }^{11}$ In underdeveloped countries, however, infection with this organism is more common in children and is associated with a higher overall incidence of seropositivity in adults. ${ }^{11}$

In children the association between gastric colonisation with $H$ pylori and antral gastritis has also recently been established. ${ }^{12-16}$ The association of $H$ pylori with recurrent abdominal pain in children ${ }^{17}$ introduces a further identifiable organic cause of this condition. Consequently, non-invasive serological detection of $H$ pylori infection may be impor- tant in the differential diagnosis of such children. Recently systemic immune responses to $H$ pylori in children undergoing endoscopy were examined by enzyme linked immunosorbent assay (ELISA). ${ }^{18-21}$ Some studies suggest a possible diagnostic role for $H$ pylori serology in children with chronic abdominal pain. These have, however, been based on only a very limited number of positive children ${ }^{21}$ in largely adolescent populations. ${ }^{2021}$ The development of a full systemic immune response to $H$ pylori can take several months following initial infection. ${ }^{22}$ As $H$ pylori infection in children is likely to be relatively recently acquired, the systemic antibody response to this bacterium may not be fully established, particularly in younger subjects. For accurate diagnosis in children seropositivity should be determined using sera from local children of known $H$ pylori response rather than asymptomatic control sera.

\section{Methods}

Sixty nine children (mean age 10.8 (SEM 2.9 ), range 1 to 16 years) undergoing upper gastrointestinal endoscopy were investigated. The project was approved by the local research committee (ethics) of Leeds Eastern Health Authority. Sera obtained at the time of endoscopy were stored at $-20^{\circ} \mathrm{C}$ until assayed. Endoscopy was performed using paediatric endoscopes (Olympus GIF P3, Fujinon UGI PE) under intravenous sedation with Diazemuls $(0.5-1.0 \mathrm{mg} / \mathrm{kg}$, maximum $20 \mathrm{mg}$ ). In all patients a minimum of two biopsy specimens were taken from the gastric antrum for histological examination. Sections of antral biopsy specimens were stained with haematoxylin and eosin to determine the presence of gastritis using Whitehead's criteria. ${ }^{23} \mathrm{H}$ pylori were detected histologically using a modified Giemsa stain.

\section{ELISA}

Sera were assayed for $H$ pylori IgG, IgA, and IgM antibodies by an ELISA. Flat bottomed microtitre plates (Falcon 3912, Becton Dickinson, Oxford) were coated with $100 \mu$ l ultracentrifuged (100000 $\times g$ for one hour) sonicated antigen preparation $(3.5 \mu \mathrm{g} / \mathrm{ml})$ from one strain of $H$ pylori diluted in coupling buffer (0.1 M bicarbonate buffer, $\mathrm{pH} 9.6)$ for 24 hours at $4^{\circ} \mathrm{C}$. After washing (phosphate buffered saline (PBS) containing $0 \cdot 1 \%$ Tween20) and blocking with $0.5 \%$ bovine serum albumin (BSA), sera diluted in PBS-Tween containing $1 \%$ BSA were assayed in triplicate. Serum dilutions were 1 in 200 for IgG and IgM, and 1 in 50 for IgA. After incubation 
with goat-antihuman IgG, IgM, and IgA alkaline phosphatase conjugates bound antibodies were detected with p-nitrophenyl phosphate substrate (Sigma) solution at 1 $\mathrm{mg} / \mathrm{ml}$ in diethanolamine- $\mathrm{MgCl}_{2}$ buffer. The reaction was stopped with $3 \mathrm{M} \mathrm{NaOH}$ and the absorbance read at $405 \mathrm{~nm}$ in a Bio-Rad 2550 EIA ELISA reader. A standard curve of positive control sera and negative controls were included on each plate. Sera were assayed without knowledge of the endoscopic and histological diagnoses.

To determine the sensitivity and specificity of the $H$ pylori IgG ELISA, a cut-off point of 2 standard deviations above the mean value of $H$ pylori negative children was used. To compare cut-off points for determining seropositivity in the $H$ pylori IgG ELISA an intra-assay comparison of paediatric and adult sera was undertaken using sera of 40 endoscoped adults (mean age $45.3(18.4)$ ) with normal antral histology and no evidence of $H$ pylori colonisation.

\section{SODIUM DODECYLY SULPHATE-POLYACRYLAMIDE GEL ELECTROPHORESIS (SDS-PAGE) AND} IMMUNOBLOTTING

$H$ pylori (NCTC 11637 strain) grown microaerobically for 72 hours on Columbia agar (Oxoid, Basingstoke) with 7\% defibrinated horse blood was harvested into $10 \mathrm{mM}$ TRIS buffered saline (TBS) (pH 7.4). Cells were washed twice in TBS and whole cell sonicates were prepared in sample buffer ( 80 $\mathrm{mM}$ TRIS hydrochloride, $\mathrm{pH} 6 \cdot 8$, containing $5 \% 2$-mercaptoethanol, $2 \cdot 5 \%$ SDS, $10 \%$ (vol/ vol) glycerol and $2 \mathrm{mM}$ phenylmethylsulphonylfluoride). Samples containing $300 \mu \mathrm{g}$ of protein were separated by SDS-PAGE using a $12.5 \%$ separating gel and $5 \%$ stacking gel and transferred to nitrocellulose paper by semi-dry blotting ${ }^{24}$ using an LKB NovaBlotter. Molecular weight markers (Sigma) were run on each gel. After blocking in TBS containing $0.25 \%$ Tween-20 the nitrocellulose was incubated for two hours in sera diluted in TBS-Tween containing $20 \%$ fetal calf serum in a miniblotter apparatus (Biometra, Manchester). Serum dilutions of 1 in 50 ( $\operatorname{IgG}), 1$ in $25(\operatorname{IgM}, \operatorname{IgA})$, and 1 in 10 (IgA, IgG) were used. After washing in TBSTween bound antibodies were detected by sequential incubation with alkaline phosphatase conjugated goat antihuman IgG, IgA, or IgM ( 1 in 500 dilution in TBS-Tween containing $20 \%$ fetal calf serum) and 5bromo-4-chloro-3-indolyl phosphate and nitro blue tetrazolium, as described previously. ${ }^{25}$

Data are expressed as means (SD). Statistical comparisons were carried out using the Mann-Whitney $U$ test for non-parametric data.

Table 1 Antral histology and H pylori positivity

\begin{tabular}{|c|c|c|c|c|c|}
\hline $\begin{array}{l}\text { Antral } \\
\text { histology }\end{array}$ & $N=$ & Age & & $\operatorname{Sex}(F / M)$ & $\begin{array}{l}\text { H pylori positive } \\
\text { by histology }\end{array}$ \\
\hline $\begin{array}{l}\text { Normal } \\
\text { Gastritis }\end{array}$ & $\begin{array}{l}47 \\
22\end{array}$ & $\begin{array}{l}10 \cdot 7 \\
11 \cdot 1\end{array}$ & $\begin{array}{l}(2.9) \\
(3 \cdot 6)\end{array}$ & $\begin{array}{l}26 / 21 \\
14 / 8\end{array}$ & $\begin{array}{r}0 \\
21\end{array}$ \\
\hline
\end{tabular}

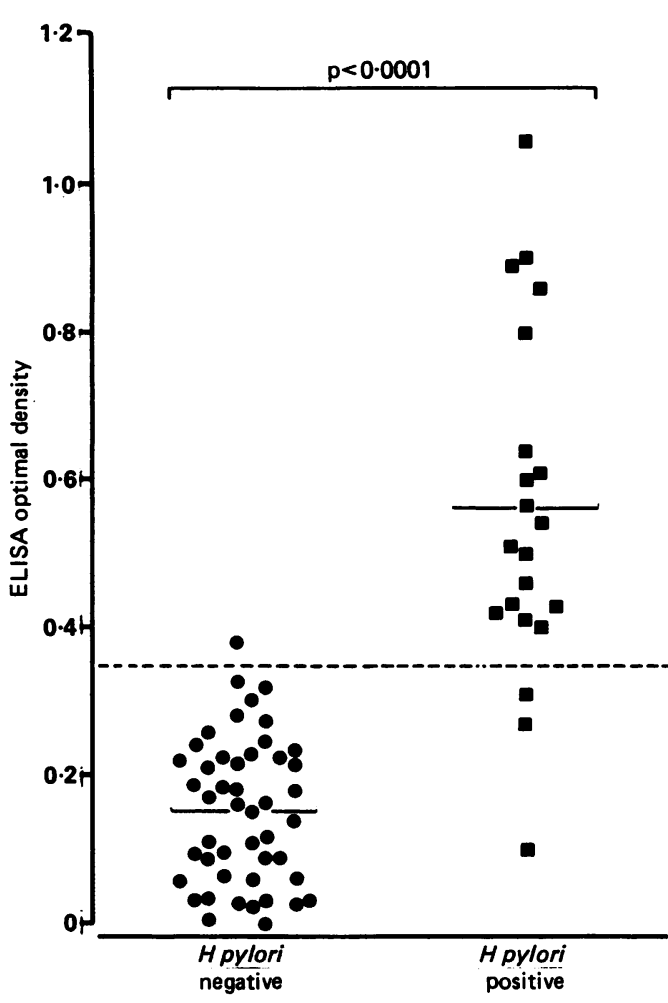

Figure 1 Serum $H$ pylori IgG antibody titres in $H$ pylori negative children with normal antral histology and children with $H$ pylori associated gastritis.

\section{Results}

Twenty two of the children had histological gastritis and 47 had normal antral mucosa (table 1). $H$ pylori was identified histologically in 21 of the patients with gastritis. The gastritis in seven $H$ pylori positive patients (33\%) was inactive. One patient with lymphocytic gastritis $^{26}$ was histologically negative for $H$ pylori. None of the children with normal antral mucosa were $H$ pylori positive on histological examination.

ELISA

Children with $H$ pylori associated gastritis had significantly higher titres $(p<0.001)$ of $H$ pylori IgG antibodies by ELISA, mean (SD) optical density $0.56(0.23)$, than those with normal gastric histology and no evidence of $H$

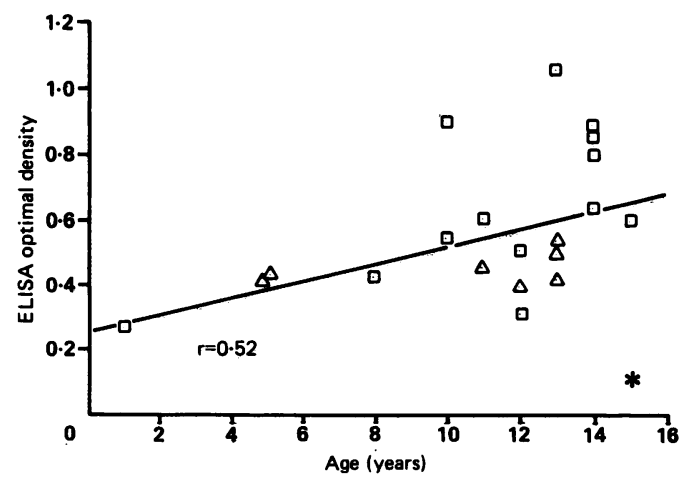

Figure 2 Relation between age and optical density in $H$ pylori IgG ELISA in H pylori positive children: $p<$ $0.05, r=0.52$, excluding subject who was negative for $H$ pylori IgG antibodies by immunoblotting. $\triangle$ children with inactive gastritis. 


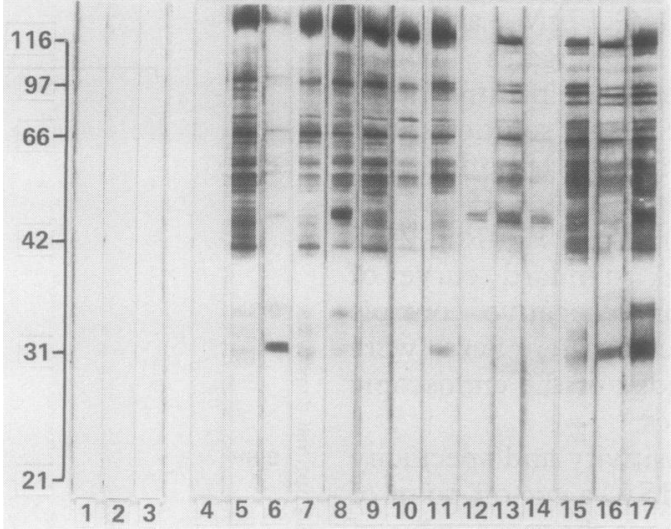

Figure 3 Western blot of IgG antibodies to whole cell proteins of $H$ pylori. Tracks $1-3$ sera of $H$ pylori negative children with normal antral histology, tracks 4-17 sera of $H$ pylori positive children. Patient in track 4 showed some positivity in IgA and IgM immunoblots but was

seronegative in the IgG ELISA. Left hand figures refer to molecular weight standards in kilodaltons.

pylori colonisation $(0 \cdot 15(0 \cdot 098))$ (fig 1). The one histologically negative $H$ pylori subject with lymphocytic gastritis was strongly $H$ pylori seropositive by ELISA. The relation between age and optical density in the IgG ELISA for subjects with $H$ pylori associated gastritis is shown in fig 2. Increased optical densities were evident in older children with $H$ pylori infection. Exclusion of one seronegative subject (the only child with $H$ pylori associated gastritis negative for IgG $H$ pylori antibodies by immunoblotting) from analysis showed a significant positive correlation $(\mathrm{p}<0.05)$ between $H$ pylori $\mathrm{IgG}$ antibody titres and patient age $(r=0.52, \mathrm{n}=20)$. Subjects with inactive gastritis generally had lower $H$ pylori IgG antibody titres than those with active gastritis (fig 2). No significant increase in $\mathrm{H}$ pylori specific IgM or IgA antibodies was evident in children with $H$ pylori associated gastritis.

Based on a cut-off of 2 standard deviations above the mean of $H$ pylori negative children with normal histology, three of the histologically positive subjects were seronegative and 18 were positive. Conversely, one histologically negative patient with normal gastric mucosa was seropositive. The sensitivity and specificity of the IgG ELISA were therefore $86 \%$ and $98 \%$, respectively. Intra-assay comparison of adult $H$ pylori negative sera with negative paediatric sera showed an increased adult mean optical density $(0 \cdot 187(0 \cdot 17))$ in the IgG ELISA relative to paediatric sera. The cut-off for positivity for adult sera was thus greater than that for paediatric sera. Use of the latter criteria for positivity would have resulted in only 10 of the 21 children with $H$ pylori gastritis being considered seropositive in the IgG ELISA.

Table 2 Western blotting analysis of serum $H$ pylori antibodies in children with $H$ pylori associated gastritis

\begin{tabular}{lccc}
\hline & $\operatorname{Ig} G$ & $\operatorname{Ig} M$ & $\operatorname{Ig} A$ \\
\hline Positive & 20 & 4 & 6 \\
Negative & 1 & 17 & 15 \\
\hline
\end{tabular}

\section{IMMUNOBLOTTING}

Twenty of the 21 children with $H$ pylori associated gastritis and the subject with lymphocytic gastritis were positive for $\mathrm{H}$ pylori IgG antibodies by immunoblotting ( $95 \%$ sensitivity). No positivity was observed in $\mathrm{H}$ pylori negative subjects with normal antral mucosa (fig 3). Two of the three ELISA seronegative children with $H$ pylori were positive in IgG immunoblots, including the youngest patient aged 13 months. The third subject, although negative for IgG antibodies by immunoblotting, showed a positive reaction with 31 and 61 kilodalton proteins in IgM and IgA immunoblots, respectively. Major $H$ pylori antigens recognised by the IgG response included 120, $90,61,53,45$ and 31 kilodalton proteins (fig 3). Two positive patients showed no IgG recognition of the 120 kilodalton protein (fig 3). Limited immunoreactivity in IgM immunoblots was evident in only four of the 21 subjects with $H$ pylori (table 2). At a serum dilution of 1 in $10 \mathrm{IgA}$ antibodies were observed in six of the 21 children with $H$ pylori (table 2 ), but in four subjects reactivity was limited to only one antigenic band (61 kilodaltons).

\section{Discussion}

The identification of $H$ pylori infection in children and its association with gastritis ${ }^{12-16}$ and peptic ulceration ${ }^{27}$ makes non-invasive serological diagnosis of infection important in the management of children with recurrent abdominal pain. In this study we characterised the systemic immune response to $H$ pylori using ELISA and immunolotting techniques. IgG immunoblotting, with its increased sensitivity, proved a useful adjunct for determining seropositivity of patients whose ELISA values were borderline.

The IgG ELISA sensitivity and specificity in this study are similar to those previously reported. ${ }^{182021}$ Both the age of presentation and length of duration of symptoms are likely to influence the sensitivity of $H$ pylori ELISAs. A significant increase in $H$ pylori IgG antibodies, determined by ELISA, occurred with increasing age in positive children. One of the two ELISA negative subjects who was positive by immunoblotting was only 13 months of age and presumably infection had been recently acquired. Maximal concentrations of IgG are not evident until the ages of 7 to $10^{28}$; this is an important consideration when determining seropositivity in younger children.

The sensitivity and specificity of the ELISA will be influenced by the chosen cut-off point. ${ }^{3}$ Our study clearly shows the importance of using age matched negative controls to achieve optimal sensitivites. With commercial $\mathrm{H}$ pylori ELISAs now available, ${ }^{29}$ it is important that they should be verified with control sera of children before being used in paediatric practice.

Although $H$ pylori specific IgA antibodies have been reported ${ }^{48}$ and a diagnostic role for IgA proposed, no specific $H$ pylori IgA antibodies were detected by ELISA in this 
study, although limited IgA positivity was determined by immunoblotting in six subjects. Other studies have similarly not detected a strong systemic IgA response to $H$ pylori. ${ }^{3}$ IgM immunoblotting of adult sera has, as in this study, shown little evidence of a specific IgM response. ${ }^{30}$ Interestingly, the only $H$ pylori positive subject who had no detectable IgG response by immunoblotting, showed some positivity in IgM immunoblots that was suggestive of an early infection. The development of the systemic immune response to $H$ pylori following infection has not been examined in detail. Our recent observations in a case of acute gastritis have shown that despite a rapid mucosal IgA and IgM response to the bacterium, systemic IgG responses take some time to develop fully and there was little evidence of a systemic IgM response. ${ }^{22}$

Western blot analysis of adult serum IgG responses to $H$ pylori has shown the antigenicity of $110-120,89,61,54$ and 31 kilodalton proteins, although considerable variability in recognition in individual patients has been described. ${ }^{30} 31$ Czinn et al observed an IgG response in children to 61,54 , and 32 kilodalton outer membrane proteins but no recognition of a 120 kilodalton protein as observed in this study. ${ }^{19}$ This latter protein is not expressed in all strains of $\mathrm{H}$ pylori, ${ }^{32}$ and in this study two positive children clearly showed no recognition of the 120 kilodalton antigen. The inclusion of the 120 kilodalton protein in ELISA antigen preparations has been shown to increase the sensitivity of the assay. ${ }^{33}$

In conclusion, $H$ pylori ELISA and immunoblotting techniques are sensitive and specific tests for determining gastric infection with $H$ pylori. Serological testing of children with recurrent abdominal pain for $H$ pylori antibodies will identify those subjects who warrant further investigation and avoid unnecessary invasive investigations in seronegative children.

This study was carried out with financial support from the Yorkshire Regional Health Authority and Glaxo plc.

1 Marshall BJ, Warren JR. Unidentified curved bacilli in the stomach of patients with gastritis and peptic ulceration. Lancet 1984;i:1311-4.

2 Dixon MF. Campylobacter pylori and chronic gastritis. In Rathbone GJ, Heatley RV, eds. Campylobacter pylori and gastroduodenal disease. Oxford: Blackwell Scientific Publications, 1989:106-16.

3 Goodwin CS, Blincow E, Petersen G, et al. Enzyme-linked immunosorbent assay for Campylobacter pyloridis: correlation with presence of $C$ pyloridis in the gastric mucosa. J Infect Dis 1987;155:488-94.

4 Perez-Perez GI, Dworkin BM, Chodos JE, Blaser MJ. Campylobacter pylori antibodies in humans. Ann Intern Med 1988;109:11-7.

5 Dent JC, McNulty CAM, Uff JS, Gear MWL, Wilkinson SP. Campylobacter pylori urease: a new serological test. Lancet 1988;i:1002.

6 Evans DJ, Evans DG, Graham DY, Klein PD. A specific and serologic assay for the detection of $C$. pylori infection. Gastroenterology 1988;96:1004-8.
7 Rathbone BJ, Wyatt JI, Worsley BW, et al. Systemic and local antibody responses to gastric Campylobacter local antibody responses to gastric Campylobacter
pyloridis in non-ulcer dyspepsia. Gut 1986;27:642-7.

pyloridis in non-ulcer dyspepsia. Gut 1986;27:642-7.
8 Steer HW, Hawtin PR, Newell DG. An ELISA technique for the serodiagnosis of $C$ pyloridis infection in patients with gastritis and benign duodenal ulceration. Serodiagn Immunother 1987;1:253-9.

9 Sobala GM, Rathbone BJ, Wyatt JI, Dixon MF, Heatley RV, Axon ATR. Investigating young patients with dyspepsia. Lancet 1989;i:50-1.

10 Morgan AG, Crabtree JE, Heatley RV, Goodwin PGR. Role of $H$. pylori serology in initial assessment of patients with dyspepsia. Gut 1991;32:A570.

11 Megraud F, Brassens-Rabbe MP, Denis F, Belbouri A, Hoa DQ. Seroepidemiology of Campylobacter pylori infection
in various populations. J Clin Microbiol 1989;27:1870-3.

12 Drumm B, O'Brien A, Cutz E, Sherman P. Campylobacter pylori-associated primary gastritis in children. Pediatrics 1987;80:192-5.

13 Glassman MS, Schwarz SM, Medow MS, et al. Campylobacter pylori-related gastrointestinal disease in children. Incidence and clinical findings. Dig Dis Sci 1989;34: $1501-4$.

14 Cadranel S, Goosens H, De Boeck M, Malengreau A, Rodesch P, Butzler JP. Campylobacter pyloridis in childhood. Lancet 1986;i:735-6.

15 Drumm B, Sherman P, Cutz E, Karmali M. Association of Campylobacter pylori on the gastric mucosa with antral gastritis in children. $N$ Engl $J$ Med 1987;316:1557-61.

16 Mahony MJ, Wyatt JI, Littlewood JM. Campylobacter pylori gastritis. Arch Dis Child 1988;63:654-5.

17 Mahony MJ, Littlewood JM. Campylobacter pylori in paediatric populations. In: Rathbone BJ, Heatley RV, eds. Campylobacter pylori and gastroduodenal disease. Oxford: Campylobacter pylori and gastroduodenal disease.

18 Odera G, Vaira D, Holton J, Dowsett JF, Ansaldi N. Serum pepsinogen 1 and IgG antibody to Campylobacter pylori in non-specific abdominal pain in childhood. Gut 1989; 30:912-6.

19 Czinn S, Carr H, Sheffler L, Aronoff S. Serum IgG antibody to the outer membrane proteins of Campylobacter pylori in children with gastroduodenal disease. J Infect Dis 1989;159:586-9.

20 Drumm B, Perez-Perez GI, Blaser MJ, Sherman PM. Intrafamilial clustering of Helicobacter pylori infection. N Engl J Med 1990;322:359-63.

21 Glassman MS, Dallal S, Berezin SH, et al. Helicobacter pylori-related gastroduodenal disease in children. Diagnostic utility of enzyme-linked immunosorbent assay. Dig Dis Sci 1990;35:993-7.

22 Solala GM, Crabtree JE, Dixon MF, et al. Acute Helicobacter pylori infection: clinical features, local and systemic immune responses, gastric mucosal histology and gastric juice ascorbic acid concentrations. Gut 1991;32(in press)

23 Whitehead R, Truelove SC, Gear MWL. The histological diagnosis of chronic gastritis in fibreoptic biopsy specimens. J Clin Pathol 1972;25:1-11.

24 Kyhse-Anderson J. Electroblotting of multiple gels: a simple apparatus without buffer tank for rapid transfer of proteins from polyacrylamide to nitrocellulose. J Biochem Biophys Methods 1984;10:203-9.

25 Blake MS, Johnston KH, Russel-Jones GJ, Gotschlich EC. A rapid, sensitive method for detection of alkaline phosphatase-conjugated anti-antibody on Western blots. Anal Biochem 1984;136:175-9.

26 Dixon MF, Wyatt JI, Burke DA, Rathbone BJ. Lymphocytic gastritis-relationship to Campylobacter pylori infeccytic gastritis-relationship to Camp

27 Yeung CK, Fu KH, Yuen KY, et al. Helicobacter pylori and duodenal ulcer. Arch Dis Child 1990;65:1212-6.

28 Plebani A, Ugazio AG, Avanzini MA, et al. Serum IgG subclass concentrations in healthy subjects at different age: age normal percentile charts. Eur J Pediatr 1989;149: 164-7.

29 Crabtree JE, Shallcross TM, Heatley RV, Wyatt JI. Evaluation of a commercial ELISA for serodiagnosis of Helicobacter pylori infection. J Clin Pathol 1991;44: 326-8.

30 Von Wulffen H, Grote HJ, Gaterman S, Lonig T, Berger B, Buhl C. Immunoblot analysis of immune response to Campylobacter pylori and its clinical associations. J Clin Pathol 1988;41:653-9.

31 Newell DG. Human serum antibody responses to surface protein antigens of Campylobacter pyloridis. Serodiagn protein antigens of Campyl

32 Apel I, Jacobs E, Kist M, Bredt W. Antibody response to patients against a $120 \mathrm{kDa}$ surface protein of Campylobacter pylori. Zbl Bakt Hyg A 1988;268:271-6.

33 Hirschl AM, Rathbone BJ, Wyatt JI, Berger J, Rotter ML. Comparison of ELISA antigen preparations alone or in combination for serodiagnosing Helicobacter pylori infections. J Clin Pathol 1990;43:511-3. 